\title{
Bilingual Education in Australia
}

Joseph Lo Bianco, The University of Melbourne

Yvette Slaughter, The University of Melbourne

Level 2, 100 Leicester St, The University of Melbourne, 3010, Australia

\section{Keywords:}

\section{Abstract}

The Australian experience of bilingual education is composed of three separate audiences: Indigenous groups and their languages, immigrant groups and their languages (both of these groups seeking language maintenance and intergenerational vitality), and mainstream English speakers seeking additive language study. All these interests share a common aim of lobbying for more serious and substantial language education programs, but differ significantly in the purposes and context of their promotion of bilingual education. This chapter provides an overview of historical, political and educational influences on forms of bilingual education that have emerged, in the context of state and national language policy and practices, to meet the needs of Indigenous Australians, migrant communities, and Anglophones.

\section{Introduction}

During the past 40 years, deep transformations to the demographic and economic landscape of Australia have stimulated intense multilingual policy activity. Since the early 1970 s language policy has often functioned as a tool of national reconstruction, focusing on broad social aims at different times, for "multiculturalism", "Asia literacy", "globalisation", "international economic competitiveness", or "Indigenous reconciliation" (see Lo Bianco \& Slaughter, 2016; Lo Bianco \& Slaughter, 2009; Lo Bianco \& Aliani, 2013).

Despite inconsistent aims, changing priorities, and inadequate implementation, the overall result of this stream of ambitious and occasionally well-resourced policymaking has been a multilingual practice through which teaching and examining occurs in some 100 of Australia's 300 spoken languages (Clyne, 2005); languages categorised as international, immigrant or Indigenous. International languages historically were the prestige Europeans (French, Latin and German) but today are Asian trade languages: Chinese (Mandarin), Indonesian and Japanese, occasionally also Hindi and Korean. Although mostly promoted as though their speakers are foreigners, all are present within the Australian population. Such domestic multilingualism involves what are called "community languages" broadly equivalent to what others call "heritage languages". All have local speaker populations who typically advocate for intergenerational language retention, but by definition have linguistic settings outside of Australia, while Indigenous languages have been unique to the Australian continent for millennia.

The bulk of education programming involves teaching languages as a timetabled school subject, a practice reinforced from 2014 with the adoption of Australia's first national curriculum. The most persistent and sometimes dramatic question in bilingual education concerns Indigenous languages specifically the role of traditional languages in how general education, English learning and literacy teaching for Indigenous Australians', should be imparted.

This chapter provides an overview of historical, political and educational influences on forms of bilingual education that have emerged, in the context of state and national language policy and 
practices, to meet the needs of Indigenous Australians (variously multilingual speakers of unique languages, dialectsii such as Aboriginal English, creole languages such as Kriol and mixed languages such as Gurindji Kriol and Light Warlpiri (Meakins, 2014)); migrant communities, and Anglophones. See also: Joseph Lo Bianco \& Yvette Slaughter: Language Policy and Education in Australia (Vol 1).

\section{Early Developments}

\section{Bilingual programs in Australian schools}

With instructions from King George III to establish a British Colony, Captain Arthur Phillip and the "First Fleet" of 11 ships and 1,350 people landed at Botany Bay in January 1788 (Welsh, 2004). The subsequent struggles to establish permanent settlement and expand colonisation to incorporate the entire land mass of Australia involved massive dislocation of the Indigenous peoples, importation of large numbers of convict and then free settlers, and the creation of institutions and expansion of cities (Hughes, 1996). By the 1860s, in addition to around 250 Indigenous languages iii, a multitude of immigrant languages were present, with Irish, German, Chinese, Gaelic, Welsh, French, Scandinavian languages and Italian predominating (Dixon, 1989; Clyne 1991). As the century proceeded, gold and wool industries produced a booming economy and burgeoning population, but also stoked moves towards unification of the six self-governing British territories, culminating in a series of conventions and referenda during the 1890s and ultimately 1901 political federation as the Commonwealth of Australia (Macintyre, 2009).

Nineteenth century society consisted of Indigenous communities, immigrant settlers and convicts, and native-born Europeans, mostly of British or Irish origin, but also from Africa, Asia, Europe and South America. However, in this context of rapid settlement and institution-creation, an absence of overt language policy permitted broadly tolerating practices, at least for non-Indigenous groups. Demographic diversity was expressed in various forms of bilingual education from the 1850s, with programs mostly designed for individual ethnic or religious groups, some of which attracted large enrolments from children of English speaking families, so that by 1900 over 100 bilingual schools (French, German, Hebrew and Gaelic) operated throughout the colonies (Clyne, 1991).

Despite the immense diversity of Aboriginal languages and their linked education systems which together encompass 'a broad range of practical, spiritual and cultural skills' (Barry, 2008, p. 241), colonial administration repudiated any understanding of the ancient Indigenous presence in Australia as a unique human civilisation. Instead, all education was premised on the overriding aim of 'civilising' the Indigenous populations 'by inculcating Christian habits and the wider values of Europeans' (Beresford, 2012, p.83). While missionaries also embraced this 'civilising' mission, their more specific aim was inculcating Christian faith, and although vernaculars were sometimes utilised in the complex trajectories between colonisers and colonised (see e.g. Mills 1982; Barry 2008; van Toorn 2006), there is little evidence of any formal Indigenous language bilingual education during the nineteenth or the early twentieth centuries.

Population control dominated early Federation politics, with adoption of the Immigration Restriction Act of 1901 (White Australia Policy), progressively compounded by rivalry and war between Britain and Germany. Empire loyalty among many Australians and active participation in battlefields in France and Turkey, however, stoked independence-minded nationalism even as it provoked enactment of legislation in several states to curtail German bilingual education, effectively ending the previous tolerant approach towards ethnic and linguistic difference. Promotion of English monolingualism, modelled on Southern British norms, continued uninterrupted until the 1947 Post War Immigration Program which injected a vast new settler population drawn from non-English sources. By that stage, however, xenophobia allied to patriotism and resulted in closure of bilingual schools, and a decisive shift against linguistic pluralism (Clyne, 1991). 


\section{Major Contributions}

Post War Migration

Under Prime Minister Ben Chifley and Immigration Minister Arthur Calwell, in 1947 the

Commonwealth government commenced a vast population growth scheme under the slogan

"populate or perish". The aim was to increase population by one percent annually from immigration, with 9/10ths of new arrivals to be British. The one percent target remained until 1972, reduced by the Whitlam government, which also removed national origin discrimination, thereby ending the White Australia Policy. By the late 1990s the scheme generated over 6.5 million new permanent settlers. Between 1953 and the late 1960s southern Europeans exceeded British arrivals, financial favoritism after 1968 restored the British primacy until the mid-1980s when Vietnamese or IndoChinese arrivals became the largest national origin, and since 1983, English-speaking arrivals have been significantly below Asian immigration (Price, 1998).

Considerable pressure was applied to European migrants to discard their cultures and languages and rapidly assimilate (Clyne 1991), but activist second generation European Australians were ultimately catalysts in expansion and development of multilingual services and education policy (Ozolins, 1993), transforming the wider national context of bilingual education. Under their pressure and leadership, bilingual programs re-emerged in the education landscape during the early 1970s.

\section{Indigenous bilingual education}

Indigenous bilingual education required a separate struggle around citizenship rights and recognition, civil activism by both urban and rural Indigenous people and their supporters around fundamental rights such as land rights, wage parity and access to government financial services, as well as demands to remain connected to their languages and culture (Maynard, 2007). In education, Indigenous children had endured decades of extreme assimilationism, taught to read and write exclusively in English under curricula that provided little acknowledgement of their cultural backgrounds. Claims for incorporation of Indigenous vernaculars informally in early grades to improve learning effectiveness were usually repudiated with arguments that improved learning outcomes required rigorous application of English-only teaching (Mills, 1982).

In 1972 a radical move by Prime Minister Gough Whitlam saw the introduction of bilingual teaching for Indigenous children in the Northern Territory; from 1973, five schools introduced bilingual education, expanding quickly so that by 1981 , half of enrolled Indigenous primary aged children were receiving bilingual teaching in one of 13 languages, with smaller numbers in other states (Mills, 1982). Even these early innovations were accompanied by vacillation and cautions from state and national officials about the overriding primacy of English literacy; hesitancy which has regularly impeded full implementation of bilingual education. After achieving self-government in 1978 the Northern Territory modified the educational and linguistic aims of the bilingual programs it inherited to stress their exclusively transitional role as a bridge to English-mediated learning, distancing language maintenance from the core purposes of the programs. The 'step' approach it adopted involved instrumental use of vernacular literacy in the early years, accompanied by oral English support and full introduction of English literacy by Year 4, but regular modifications continually shifted the focus to English (Simpson, Caffery \& McConvell, 2009; Devlin, 2011; McKay, 2011).

Bilingual programs were destabilized by inadequate program costing, high non-Indigenous staff turnover (up to 100 percent annually) and regular absenteeism among Indigenous support workers, who were critical for the success of team teaching. A shortage of trained Indigenous teachers, slow orthographic development and literature production, absent agreement on terminology, and irregular attendance by students also impacted bilingual programs negatively, compounded by high 
family mobility, endemic poverty, health problems, especially ear and hearing illnesses, and even community violence (Simpson, et al. 2009).

With increasing national focus on English literacy as a priority for educational intervention from the late 1990s, (Lo Bianco, 2008) and ongoing negative discourse around bilingual education from some political corners, in 1998, the Northern Territory government attempted to abolish bilingual programs. In response to vocal opposition and petitioning, a report was commissioned into program "viability". The report, Learning Lessons, showed strong community support for their continuation, and demands for appropriate teacher training in bilingual methodologies. The report also proposed modification to the contested concept of "bilingual education", suggesting its replacement with "Two-Way Learning" (Simpson et al., 2009). The Northern Territory government adopted Two-Way Learning, but no other recommendations. Though broadly similar to the preceding bilingual programs, Two-Way programs, according to Simpson et al. (2009), were essentially watered-down versions of bilingual programming .

Most Indigenous children enter education as speakers of creoles such as Kriol, mixed languages such as Gurindji Kriol and Light Warlpiri (Meakins, 2014), or dialects such as Aboriginal English, and therefore are learners of English as an Additional Language or Dialect (EAL/D). Few Indigenous children in remote contexts have extended exposure to Standard Australian English (SAE), or full knowledge of a traditional language, and yet many teachers lack training in appropriate EAL/D methodology (Simpson et al., 2009). This deficiency in how English is taught, and how complex multilingual/multi-dialectalism is understood, impacts on effectiveness of bilingual approaches. Along with the introduction of Two-way programs, support for English as a second language/dialect services was disastrously decreased, so that bilingual education was prepared for eventual closure.

Even when recognition of Indigenous rights was achieved through litigation or referenda, it was hampered by administration and implementation. Most significant was the foundational case for native title, the 1992 Mabo v Queensland ruling, a landmark decision of the High Court. The Mabo decision recognised that a state of un-extinguished native land title survives British colonial claims to the entire Australian continent, based on rejection of the doctrine of terra nullius - that the land belonged to no one when the British arrived. Native title pre-existed British occupation and its continuity is now established through cultural connection to land, often through continuous use of Indigenous language, culture and law.

Erosion of programs can occur even under supportive policy, via language prejudice entrenching an elevated status of Standard English over traditional languages (Truscott \& Malcolm, 2010); practices which serve as invisible language policy privileging mono-lingualism or ranking some bi-lingualisms above others, or misunderstanding of language sequencing, and integration of cognitive functioning across languages, which are key premises on which bilingual education is based. Sociolinguistic complexity compounds the delivery of bilingual education when the latter is assumed to involve discrete languages, evident in the failure of curricula and assessment to recognise that many Indigenous students are English as a second language/dialect learners.

Beyond the Northern Territory, other states have introduced and supported Indigenous languages teaching, occasionally in bilingual mode, especially the largest states, New South Wales and Victoria, and in the national curriculum, an Indigenous languages framework is a major achievement. Despite these efforts, Indigenous language programs remain fragile and vulnerable within any education jurisdiction (McKay, 2011). 
The development of bilingual programs for migrants and majority speakers of English Alongside Indigenous activism for bilingual education rights, a parallel and much larger activity on behalf of bilingual schooling was a direct consequence of the settlement/citizenship basis of post war migration. The sheer number of new arrivals led to the society-changing movements of multicultural, non-assimilationist policies that have since shaped general language policy. With thousands of migrant children from non-English backgrounds entering schools, education planners turned from "foreign" language teaching to responding to the urgent need to maximise immigrant children's general education, English and first or home language knowledge. The general educational presence of foreign language teaching was affected by these moves, though such programs of cultural enrichment and development of linguistic skills for monolingual Englishspeaking students remained.

Through the 1970 s and 80 s, numerous forms of bilingual education were developed, although significant regional differences became evident ${ }^{v}$. A number of transitional programs, where students begin schooling in their home language, transferring to English-medium schooling close to the middle primary years, were introduced in Catholic schools in South Australia (Italian), New South Wales (Greek and Macedonian) and Victoria (Italian, Croatian and Maltese). Several Greek programs were also initially set up in Victorian government schools (Mills, 1982), later expanding to include Auslan (Australian Sign Language), Chinese (Mandarin), Macedonian and Vietnamese. However, many were intended to support English acquisition, rather than valuing and developing the emerging bilingualism of students (Lo Bianco 2008). Other groups set up community owned "independent" schools, some with religion as an integral part of their mission, including Greek Orthodox and Jewish schools with partial, full or late bilingual immersion streams (Mills, 1982).

These innovations were challenged by many of the same factors impacting on Indigenous bilingual programs. The mobility of migrant communities decreased speaker concentration and threatened program viability. Parental desire for early demonstrations of English proficiency created pressure for rapid transition out of home languages, limiting the time to develop mother tongue literacy and numeracy. Staff turnover was also high as many teachers were themselves members of mobile migrant communities, or were native speakers experiencing difficulty in gaining locally accepted training and accreditation (Gibbons, 1997; Mills, 1982).

By contrast, mainstream bilingual programs introduced with the promise of enhanced academic attainment and "prestige" bilingualism expanded (Lo Bianco, 2008) in government schools, often with assistance from foreign governments. Examples include French primary schools in Victoria, New South Wales and the Australian Capital Territory and a German program at Bayswater South in Victoria (Mills, 1982). In the 1990s, several bilingual programs were established through a Victorian government initiative on bilingual schooling, in Japanese, French and Indonesian. By the late 1990s, there were over 100 such programs nationally, of various forms, the majority in Melbourne (Gibbons, 1997). An enduring outcome of such experimentation is a strong practice of academic engagement with bilingual education and close interaction with schools in program design and evaluation; curriculum innovation and documentation of students' linguistic and cognitive development, on writing, literacy, and CLIL (e.g. de Courcy \& Smilevska, 2012; Fernandez, 1992; McKay \& DEETYA, 1997; Molynuex et al., 2014; Smala, 2013).

\section{The dismantling of Indigenous bilingual education}

By 2008, the Northern Territory bilingual education (Two-Way) programs were under full existential threat, this time due to statistical demonstrations of English literacy difficulties among Indigenous learners, and their mistaken attribution to bilingual teaching and claims that English literacy was being sidelined in favour of Indigenous languages (Devlin, 2011; Simpson et al., 2009). In 2007, Australia first national literacy and numeracy tests were conducted with students in Years 3, 5, 7 and 
9. NAPLAN (National Assessment Program - Literacy and Numeracy) is a norm-referenced test of English literacy and numeracy, whose results confirmed 'that Indigenous children in remote schools were not achieving acceptable standards of literacy in English and numeracy' (Simpson et al., 2009, p 27). In a detailed analysis of NAPLAN, Wigglesworth, Simpson and Loakes (2011) allege that the test is culturally biased: its norm-referenced basis underrepresents minority language learners, so that Indigenous children are unlikely to be familiar with many test terms and constructs, concluding that NAPLAN is 'linguistically and culturally unsuitable for Indigenous children' ( $p 340$; see also Simpson et al., 2009). Extensive criticism of NAPLAN, with its benchmarking against linguistic and cultural norms alien to learners speaking either a traditional language or EAL/D have had little discernible impact on policy makers or administrators. Compounding questions of cultural appropriateness was the demonstrated misinterpretation of the 2008 results (see Devlin, 2011), but the political backlash was swift. See also: Gillian Wigglesworth: Assessment in Indigenous Immersion (Vol 7).

Immediately following release of the 2008 results, a new draft policy for Northern Territory schools was issued. The First Four Hours policy mandated English-only during the first four hours of the school day, widely interpreted as the final closure for Northern Territory Indigenous bilingual education. The Northern Territory government subsequently claimed that the policy continues bilingual learning because it permits vernacular communication in morning classes as required. However, Devlin (2011) argues that the bilingual programs have well-structured systematic bilingual input, supported by an involved community, professional staff and purpose-designed materials, and the ad hoc use of vernaculars does not constitute bilingual learning.

\section{Work in progress}

In 2012, a national report was released into how Indigenous languages could help close the education achievement gap for Indigenous Australians ${ }^{\mathrm{vi}}$. Our Land Our Languages (House of Representatives, 2012) provided a comprehensive overview of the state of Australia's Indigenous languages. Important recommendations included development of a national implementation plan in line with United Nations obligations on rights for Indigenous populations, as well as proposing important work in mandatory first language use in assessment at early childhood level; adequately resourced and continuous full bilingual programs, and an alternative assessment to NAPLAN to accommodate dialect, culture and language differences.

Unfortunately none of the report's recommendations have been implemented. Prior to this a National Indigenous Languages Policy commenting on the important role that Indigenous bilingual education plays in some schools was issued (Australian Government, 2009), but since the Northern Territory's First Four Hours policy it is now difficult to determine how many biliteracy or bilingual programs remain in operation. Some kind of pragmatic bilingualism in government and nongovernment schools is in evidence nationwide, and some government support continues to be provided for transitional bilingual programs ${ }^{\text {vii }}$ (G. Dickson, personal communication, September 4, 2014). However, the emphasis is firmly on English medium curriculum delivery and downgrading of Indigenous languages in delivering any serious academic content continues.

A further review of Indigenous education was released in 2014, A Share in the Future (Wilson, 2014). This report represents yet another examination into Northern Territory Indigenous education by policy makers with little input from bilingual education specialists. Despite consultation, including numerous passionate arguments on behalf of continuation of bilingual education from local communities, the report concludes that education of Indigenous children and the entire curriculum be delivered exclusively in English, with teaching of literacy in the vernacular only where "feasible". Significant budget cuts have accompanied the downgrading of bilingual teaching, especially the reduction of the Northern Territory Indigenous Languages Support (ILS) scheme, from \$11.1 million 
to $\$ 9.5$ million, a program which finances community-based activities for maintenance and transmission of Indigenous languages (Nordlinger \& Singer, 2014).

Support for teaching Indigenous languages in non-bilingual delivery modes remains vibrant, however, particularly as many Northern Territory schools have never been able to offer bilingual programs (A. Truscott, personal communication, September 15, 2014). Indigenous languages and cultures are taught in 60 Northern Territory government schools - programs of first language maintenance, language renewal, second language learning and language awareness (House of Representatives, 2012, Cap./Chap 3).

Beyond the Northern Territory, in Western Australia, 16 Indigenous languages are taught in government schools; ten Indigenous languages are taught in 42 schools in South Australia, and Indigenous languages are studied in Queensland (both Aboriginal and Torres Strait Islander languages), New South Wales and Victoria. Unlike the vicissitudes that have damaged bilingual programs, these "second" language teaching schemes represent substantial, long-term investments, dedicated to reclaiming and perpetuating the languages of Indigenous Australians.

\section{Continuity of other bilingual programs}

The overall number of bilingual programs across Australia has decreased significantly since 2000 . Many survivors have extended histories and are well grounded in local and international research. In Victoria, 12 government schools provide either transitional (one to three years) or full (seven year) bilingual programs, either by cohort streams or by the whole school. An independent German bilingual school, Deutsche Schule and kindergarten, utilises German and Australian curricula in Victoria, while other programs include Italian, French and Mandarin in New South Wales and the Australian Capital Territory. Since 2010, four government primary schools in New South Wales have been offering bilingual programs within their schools, where subject content is taught through Korean, Japanese, Chinese or Indonesian for 5 to 7 hours a week. Reflecting long-term policy trends prioritising Asian languages, the New South Wales Education Minister argued that with Asia on Australia's doorstep, 'the program was vital to the state's future economic and social prosperity' ("Primary schools to...", 2010).

In Queensland, bilingual programs are offered in 12 schools, most in government secondary schools, such as late-onset immersion programs in Chinese, French, German, Japanese and Spanish, in which a cohort of students receives half their schooling through the languages for a three-year period. Smala, Paz \& Lingard (2012, p 374) argue that parents identify bilingual programs as 'positional goods in the global competition for good jobs' and that schools are using immersion programs as 'markers of distinction in the school market'. This demand is not limited to formal schooling. Across Australia, bilingual childcare centres operate in 16 languages, with access to seven more through family-based day care and official playgroups for pre-primary school children in 45 languages (Nejad, 2014).

\section{Problems and difficulties}

The primary obstacle for all bilingual education has been an overridingly monolingual construction of education success. The practical outcome for both Indigenous and immigrant children has been deleterious ranking of different kinds of bilingualism, effectively discounting social and cognitive value of bilingualism according to the social standing of the language paired with English. A systemic attitudinal and ideological problem derives from folk notions of sociolinguistics which work to represent Indigenous and immigrant children as labouring under the deficit of not knowing English, while other pathways towards bilingualism construct learners as acquirers of valued additional 
knowledge. These differential judgements are poignantly noted by Tom Calma, the Aboriginal and Torres Strait Islander Justice Commissioner:

It was somewhat of a cruel irony for me to read last week that NSW schools are to offer bilingual education in Asian languages. Yes, the NSW government is funding a four-year $\$ 2.25$ million program starting in 2010. The NSW Education Minister Verity Firth was reported as saying the program was vital to the state's future economic and social prosperity and the language lessons would start in kindergarten. These policy inconsistencies and hypocrisies are extremely disheartening for Aboriginal people. Unfortunately we are all too familiar with promises that are not kept - and governments seem to think they can get away with it (Calma, 2009, np).

Acquisition of instrumentally useful languages, regularly promoted in the media with trade and commercial associations, is validated by public discourse, receives encouragement and public acclamation, and enjoys supportive policies. For indigenous and most immigrant children, the home language maintenance basis of bilingual education is rarely socially validated, instead being judged as a kind of remediation of disadvantage. This divergence of esteem produces policy inconsistency between disparity of treatment of Indigenous and immigrant bilingual programs and the affirmative policy making offered to majority bilingual programs. See also Nelson Flores \& Jeff Bale: Sociopolitical Issues in Bilingual Education (Vol 5).

The national social transformations that have stimulated language policy over the past 40 years have failied to generate consistent application of a nation wide appreciation of languages as cognitive, social, and cultural resources, in addition to their economic and utlitarian applications. An additional point of difficulty is lack of differentiation between learning and language learning. Policy makers and some teacher educators conflate spoken language with literacy learning, failing to account for key aspects of second language acquisition, including syntax, vocabulary, pragmatics and sociocultural understanding, such as cultural conceptualisations (A. Truscott, personal communication, September 15, 2015). See also Tove Skutnabb-Kangas: Language Rights and Bilingual Education (Vol 5).

\section{Future Directions}

An imperative of future development is to harmonise the work of professional academic researchers, with the demand and needs of parents and communities, professional educators and policy makers. In the lead up to the adoption of the NPL in 1987, a coalition of professional and community groups, spanning all language interests, met regularly and managed to harmonise their disparate claims into a consolidated log of demands. The turbulent bilingual education story recounted here indicates that much more integration between research, teaching and language policy making, along these same lines, is needed to bring about the often proclaimed policy aim of national bilingualism. The different pathways implicated in the goal of universal bilingualism must be integrated into a continuum of language education opportunities and delivered by well designed, enduring and well taught bilingual education initiatives. The foundational task is comprehensive and effective policy, linked to credible implementation, and designed with both equitable language principles and language enrichment as dual aims. 


\section{References}

Australian Government. (2009). National Indigenous languages policy.

http://arts.gov.au/indigenous/languages. Accessed 14 September, 2014.

Barry, A. (2008) Broken promises: Aboriginal education in South-eastern Australia, 1837-1937.

Doctoral thesis, The University of Melbourne, Australia.

Beresford, Q. (2012). Separate and unequal: An outline of Aboriginal education 1900-1996. In Q Beresford, G Partington, \& G Gower (Eds). Reform and Resistance in Aboriginal Education (2nd Ed.) (pp. 85-119). Perth: University of Western Australia Publishing.

Calma, T. (2009, June 26). They are our children, this is our community. Paper presented at AIATSIS Research Symposium on Bilingual Education. National Museum of Australia, Canberra.

Clyne, M. (1991). Community Languages: The Australian Experience. Cambridge University Press.

Clyne, M. (2005). Australia's Language Potential. Sydney: University of New South Wales Press.

de Courcy, M.C. \& Smilevska, J. (2012). Writing strategies of children in a Macedonian and English bilingual program in Victoria. Babel, 47(2), 15-23.

Devlin, B. (2011). The status and future of bilingual education for remote Indigenous students in the Northern Territory. Australian Review of Applied Linguistics. 34(3), 260-279.

Dixon, R. (1989). Searching for Aboriginal Languages. Chicago: University of Chicago Press.

Fernandez, S. (1992). Room for two: A study of Bilingual Education at Bayswater South Primary School. Bayswater, Vic;: Bayswater South Primary School.

Gibbons, J. (1997). Australian bilingual education. In J Cummins \& D Corson (Eds). Encyclopedia Of Language And Education (Vol 5)(pp. 209-15). Dordrecht; Boston: Kluwer Academic Publishers.

Harris, S. \& Devlin, B. (1997) Bilingual programs involving Aboriginal languages in Australia. In J Cummins \& D Corson (Eds). Encyclopedia of Language and Education (pp. 1-14). Dordrecht; Boston: Klewer Academic Publications.

House of Representatives Standing Committee on Aboriginal and Torres Strait Islander Affairs. (2012). Our Land. Our Languages: Language learning in Indigenous Communities. Canberra: The Parliament of the Commonwealth of Australia.

Hughes, R. (1996). The Fatal Shore: A History of the Transportation of Convicts to Australia, 17871868. Harvill: London.

Lo Bianco, J. (2008). Language policy and education in Australia. In S May \& N Hornberger (Eds). Encyclopedia of Language and Education (Vol 1)(pp. 343-53). Dordrecht; Boston: Klewer Academic Publications.

Lo Bianco, J. \& Aliani, R. (2013). Language Planning and Students Experiences. Intention, Rhetoric and Implementation. Bristol: Multilingual Matters.

Lo Bianco, J. \& Slaughter, Y. (2009). Second Languages and Australian Schooling. Camberwell: Australian Council for Educational Research.

Lo Bianco, J. \& Slaughter, Y. (2016). The Australian Asia project. In G Leitner, A Hashim \& H.G. Wolf (Eds). Communicating with Asia (pp. 296-312). Cambridge: Cambridge University Press.

Macintyre, S. (2009). A Concise History of Australia (2nd ed.). Cambridge: Cambridge University Press.

Maynard, J. (2007). Fight for Liberty and Freedom: The Origins of Australian Aboriginal Activism. Canberra: Aboriginal Studies Press. 
McKay, G. (2011). Policy and Indigenous languages in Australia. Australian Review of Applied Linguistics. 34(3), 297-319.

McKay, P. \& DEETYA (Eds)(1997). The Bilingual Interface Project Report. Canberra: DEETYA.

Meakins, F. (2014, 27 October). While old Indigenous languages disappear, new ones evolve. The Conversation. https://theconversation.com/while-old-indigenous-languages-disappear-new-onesevolve-32559, Accessed 27 October, 2014.

Mills, J. (1982). Bilingual Education and Australian School: A review. Hawthorn, Vic;: Australian Council for Educational Research.

Molyneux, P., Scull, J., Aliani, R., Hiorth, A. \& Lo Bianco, J. (2014). Karen Bilingual Early Years Project Final Report. Sixth and final evaluation report to the DEECD. Melbourne: DEECD.

Nejad, K. (2014) Languages Australia. http://languagesaustralia.com.au/. Accessed 15 September, 2014.

Nordlinger, R. \& Singer, R. (2014, 27 May). Muting Indigenous language support only widens the gap. The Conversation, http://theconversation.com/muting-indigenous-language-support-only-widensthe-gap-27105. Accessed 11 September 2014.

Ozolins, U. (1993). The Politics of Language in Australia. Cambridge: Cambridge University Press.

Price, C.A. (1998). Post-War Immigration: 1945-1998. Journal of the Australian Population Association. 15(2), 115-129.

Primary schools to change languages for lessons. (2010, June 15) The Australian. http://www.theaustralian.com.au/news/latest-news/primary-schools-to-change-languages-forlessons/story-fn3dxity-1225735125930?nk=462761945715a2641291ed6975846d18. Accessed 15 September, 2014.

Sharifian, F., Truscott, A., Konigsberg, P., Malcom, I.G. \& Collard, G. (2012). 'Understanding Stories My Way' Aboriginal-English Speaking Students' (Mis)understanding of School Literacy Materials in Australian English. Perth, WA;: Department of Education.

Simpson, J., Caffery, J. \& McConvell, P. (2009). Gaps in Australia's Indigenous Language Policy: Dismantling Bilingual Education in the Northern Territory. Canberra: AIATSIS. www.aiatsis.gov.au/ files/ntru/DP242009Simpson.pdf Accessed 11 September 2014.

Smala, S. (2013). CLIL Pedagogies in Queensland. International Journal of Pedagogies and Learning. 8(3), 194-205.

Smala, S., Paz, J.B. \& Lingard, B. (2012). Languages, cultural capital and school choice: distinction and second language immersion programmes. British Journal of Sociology of Education. 34(3), 373-391.

Truscott, A. \& Malcolm, I. (2010). Closing the policy-practice gap: making Indigenous language policy more than empty rhetoric. In J Hobson, K Lowe \& S Poetsch (Eds). Re-Awakening Languages: Theory and Practice in the Revitalisation of Australia's Indigenous Languages (pp. 6-21). Sydney: Sydney University Press.

Van Toorn, P. (2006). Writing Never Arrives Naked: Early Aboriginal Cultures of Writing In Australia. Canberra: Aboriginal Studies Press.

Welsh, F. (2004). Great Southern Land: A New History of Australia. London: Allen Lane.

Wigglesworth, G., Simpson, J. \& Loakes, D. (2011). NAPLAN language assessments for Indigenous children in remote communities: Issues and problems. Australian Review of Applied Linguistics. 34(3): 320-323. 
Wilson, B. (2014). A share in the future: Review of Indigenous education in the Northern Territory, The Education Business. www.education.nt.gov.au/ data/assets/pdf file/0007/37294/A-Share-inthe-Future-The-Review-of-Indigenous-Education-in-the-Northern-Territory.pdf. Accessed 14 September, 2014.

\footnotetext{
'The term 'Indigenous' refers to both Aboriginal Australians and Torres Strait Islanders.

ii In Australia, the use of dialect for Aboriginal English is non-pejorative and widely used. The term English as an Additional Language or Dialect (EAL/D) has replaced the term English as a Second Language (ESL) in the Australian curriculum.

iii Many Indigenous languages did not survive the colonization of Australia. Languages that are not used in everyday communication are considered to be 'sleeping' by Indigenous Australians. While linguistically, languages can be categorized as 'extinct' and 'dormant', these categorizations are challenged by that of another - 'reawakening', as demonstrated by L2 speakers of Daungwurrung and Kaurna. (see http://www.ethnologue.com/country/AU/status; also based on reviewer comments).

iv It should be noted that two-way learning has been adopted and valued differently in Western Australia (A. Truscott, personal communication, September 15, 2014; Sharifian et al,. 2012).

$\checkmark$ See Mills (1982) for a full overview of language programs and models at this time.

vi See https://www.coag.gov.au/closing the gap in indigenous disadvantage for an overview of the Closing the gap in Indigenous disadvantage program.

vii E.g. the Northern Territory Education Minister's visit in August 2014 to Shepardson College to celebrate 40 years of bilingual education at the school:

https://www.facebook.com/PeterChandlerMLA/photos/a.386004441525050.1073741826.133717516753745/ 559368827521943/?type=1
} 


\section{University Library}

\section{- M M I E E R VA A gateway to Melbourne's research publications}

Minerva Access is the Institutional Repository of The University of Melbourne

Author/s:

Lo Bianco, J;Slaughter, Y

Title:

Bilingual Education in Australia

Date:

2017

Citation:

Lo Bianco, J. \& Slaughter, Y. (2017). Bilingual Education in Australia. Garcia, O (Ed.).

Lin, A (Ed.). May, S (Ed.). Bilingual and Multilingual Education, Bilingual and Multilingual Education, (3), pp.347-360. Springer International Publishing.

Persistent Link:

http://hdl.handle.net/11343/247789 